\title{
Effects of Lysozyme on Bacillus cereus 569: Rupture of Chains of Bacteria and Enhancement of Sensitivity to Autolysins
}

\author{
By D. WESTMACOTT* AND H. R. PERKINS $\dagger$ \\ Department of Microbiology, University of Liverpool, Liverpool L69 3BX
}

(Received 24 April 1979)

\begin{abstract}
Bacillus cereus 569 is known to be resistant to lysis by lysozyme because of the presence of deacetylated glucosamine residues in its peptidoglycan, and cultures continued to grow even in the presence of lysozyme at $200 \mu \mathrm{g} \mathrm{ml}^{-1}$. However, lysozyme caused rupture of the chains of bacteria and promoted the rate of autolysis in a non-growing cell suspension, causing a doubling of the rate of release of radioactively labelled wall material. Heatinactivated cells did not autolyse and were not lysed by lysozyme unless they were supplemented by unheated cells or cell-free autolysate. Enhancement of autolysin activity could also be effected by pre-treatment of heated cells with lysozyme. The action of lysozyme on isolated cell walls released some free reducing groups, indicating limited breakage of the polysaccharide chains of peptidoglycan, and it was concluded that lysozyme modified the peptidoglycan and made it more susceptible to autolysin(s). Lysozyme also enhanced the rate of septum separation and the probable significance of the results in relation to the control of cell separation is discussed.
\end{abstract}

\section{INTRODUCTION}

Cultures of Bacillus cereus are well known to be highly resistant to egg-white lysozyme. Indeed, Bergey's Manual of Determinative Bacteriology (Buchanan \& Gibbons, 1974) describes one of the properties of $B$. cereus as growth in $0.001 \%$ lysozyme. Hughes (1971), in his study of the products of cell wall digestion during autolysis of $B$. cereus NRRL 569, demonstrated the resistance of walls to lysozyme at concentrations as high as $100 \mu \mathrm{g} \mathrm{ml}^{-1}$. This resistance is due specifically to the deacetylation of $\mathrm{N}$-acetylglucosamine residues of the wall peptidoglycan (Araki et al., 1972; Hayashi et al., 1973) and this is also the factor responsible for lysozyme resistance in $B$. subtilis and $B$. megaterium (Hayashi et al., 1973). Araki et al. (1971) showed that $B$. cereus possesses a deacetylase which is specific for undegraded peptidoglycan, thus indicating that $N$-acetylglucosamine residues in the glycan are deacetylated after completion of polymerization of the peptidoglycan. The resistance conferred by this modification may offer a tool in the study of the mechanism of growth of bacterial walls and of the controlled depolymerization of walls that must occur during cell separation.

Bacillus cereus normally grows to form short chains of cells of varying length and very few single cells are present. However, we observed that treatment of growing cultures with lysozyme caused rapid breakage of the chains and promoted the autolysis of washed cell suspensions. These results demonstrated that there was some form of action of lysozyme on $B$. cereus but it was not clear whether the action was direct or mediated by autolysins. Autolysins are required for chain separation of $B$. subtilis since autolytic enzyme-deficient

* Present address: Roche Products Ltd, P.O. Box 8, Welwyn Garden City, Hertfordshire AL7 3AY.

$\dagger$ To whom requests for reprints should be addressed.

0022-1287/79/0000-8728 \$02.00 (c) 1979 SGM 
mutants grow as very long unseparated chains (Fein \& Rogers, 1976), but it is not known which of the two deficient autolysins is responsible for the chain separation in the wild type strain. Fan $(1970 b)$ showed that chain separation could be induced by exogenous autolysin in a strain of $B$. subtilis which grew as long chains at $48^{\circ} \mathrm{C}$. In the same strain, sub-lethal concentrations of lysozyme also induced significant dechaining though not as much as autolysin. In the present paper we describe investigations into the nature of lysozyme activity on B. cereus 569. Experiments were devised to determine whether lysozyme caused dechaining and enhanced rates of lysis by its direct action on limited sensitive areas of cell walls or whether autolysins were also implicated.

\section{METHODS}

Organism and cultivation. Bacillus cereus NRRL B-569 was obtained from the National Collection of Industrial Bacteria, Aberdeen (NCIB 7464). The organism was stored at $4{ }^{\circ} \mathrm{C}$ in sealed ampoules as spore suspensions in distilled water. Spores were germinated by incubating in nutrient broth for $7 \mathrm{~h}$ at $37^{\circ} \mathrm{C}$. Bacillus cereus was routinely cultured at $37^{\circ} \mathrm{C}$ in medium A2 of White (1972) containing Difco 'vitamin-free' acid-hydrolysed casein $\left(4 \mathrm{~g} \mathrm{l}^{-1}\right)$, L-cysteine. $\mathrm{HCl}\left(50 \mathrm{mg} \mathrm{l}^{-1}\right)$ and DL-tryptophan $\left(100 \mathrm{mg} \mathrm{l}^{-1}\right)$.

Chemicals and buffers. Egg-white lysozyme (Sigma) was used at $50 \mu \mathrm{g} \mathrm{m}^{-1}$ except where otherwise stated. $N$-Acetyl-D-[1- $\left.{ }^{14} \mathrm{C}\right]$ glucosamine $\left(\left[{ }^{14} \mathrm{C}\right] \mathrm{GlcNAc} ; 58 \mu \mathrm{Ci} \mu \mathrm{mol}^{-1}\right)$ was from The Radiochemical Centre, Amersham, and $N$-acetyl-D-glucosamine (GlcNAc) from Sigma. The phosphate buffer used throughout was $100 \mathrm{mM}-\mathrm{NaH}_{2} \mathrm{PO}_{4} / \mathrm{Na}_{2} \mathrm{HPO}_{4}$, $\mathrm{pH} 6 \cdot 4$; sodium barbital buffer, $\mathrm{pH} 8 \cdot 0$, was $10 \mathrm{~mm}$; ammonium acetate buffer, pH 6.4, was $10 \mathrm{~mm}$ unless otherwise stated.

Measurement of the length of cell chains. Samples for measurement of chain length were fixed by addition of an equal volume of $10 \%(\mathrm{w} / \mathrm{v})$ aqueous formaldehyde. Septa were counted in heat-fixed preparations of the bacteria stained with $0.01 \%(\mathrm{w} / \mathrm{v})$ crystal violet in wet mounts (Sargent, 1975). The degree of septation was measured by counting more than 200 chains from several microscope fields using bright field optics. The number of cells per chain was regarded as the number of septa plus one.

Total particle count. After fixation of samples by addition of an equal volume of $10 \%(\mathrm{w} / \mathrm{v})$ aqueous formaldehyde, total numbers of bacterial particles were counted in a $0.02 \mathrm{~mm}$-deep Thoma counting chamber using phase contrast optics. Any length of chain of cells was regarded as one particle.

Viable count. After incubation of cell suspensions with or without lysozyme, serial dilutions were made in phosphate-buffered saline and replicate samples were spread as soon as possible on agar plates of medium A2 with the amino acid supplements. Plates were incubated at $37^{\circ} \mathrm{C}$ overnight.

Treatments of whole bacteria with lysozyme. For growing cells, lysozyme dissolved in medium $(1 \mathrm{ml})$ to ten times the final required concentration was added to mid-exponential phase cultures $(9 \mathrm{ml})$ in $100 \mathrm{ml}$ shake flasks. Where cells were to be suspended in phosphate buffer, they were grown to an $A_{540}$ of 1.0 , washed twice with phosphate buffer by centrifugation at $2{ }^{\circ} \mathrm{C}$ and resuspended in buffer to give an $A_{540}$ of about 0.5 . Stock solutions of lysozyme dissolved in phosphate buffer were diluted tenfold on addition to washed cell suspensions. All treatments with lysozyme were by incubation at $37^{\circ} \mathrm{C}$ in a reciprocal shaking water bath.

Radioactive labelling of walls. An overnight culture $\left(A_{540}\right.$ about 2.5$)$ was further incubated at $37^{\circ} \mathrm{C}$ for $1 \mathrm{~h}$ after the addition of $50 \mu \mathrm{M}$-GIcNAc. A $0.4 \%(\mathrm{v} / \mathrm{v})$ inoculum of this culture was added to fresh medium containing $50 \mu \mathrm{M}-\left[{ }^{14} \mathrm{C}\right] \mathrm{GlcNAc}\left(2 \mu \mathrm{Ci} \mu \mathrm{mol}^{-1}\right)$ and incubation with shaking was continued for $3 \mathrm{~h}(5$ generations); after this time the $A_{540}$ was 0.5 to 0.55 . The final incorporated activity was about $7 \times 10^{4} \mathrm{~d}$.p.m. $\mathrm{ml}^{-1}$. The culture was cooled to $0^{\circ} \mathrm{C}$ and centrifuged and the sedimented cells were washed twice with phosphate buffer at $2{ }^{\circ} \mathrm{C}$. Where required, radioactively labelled cells were heated to $70^{\circ} \mathrm{C}$ for $15 \mathrm{~min}$ to inactivate autolytic activity.

Measurement of solubilization of incorporated ${ }^{14} C$. Samples $(1 \mathrm{ml})$ were taken from incubation mixtures containing appropriately treated radioactively labelled cells and immediately filtered through cellulose acetate membranes (Oxoid, $2.5 \mathrm{~cm}$ diam., $0.45 \mu \mathrm{m}$ pore size). Samples of the filtrates were taken and counted in a scintillation fluid [containing $6 \mathrm{~g}$ 2-(4'-t-butylphenyl)-5-(4"-biphenylyl)-1,3,4-oxadiazole (butyl PBD), $0 \cdot 51$ Triton X-100, 0.15 I distilled water and 11 toluene] using an Intertechnique SL30 liquid scintillation spectrometer. The membrane filters were washed twice with $2 \mathrm{ml} 50 \mathrm{~mm}$-GlcNAc and twice with $2 \mathrm{ml}$ water then dried and counted in a scintillation fluid (containing $4 \mathrm{~g}$ butyl PBD in 11 toluene). The proportion of solubilized ${ }^{14} \mathrm{C}$ was calculated as the fraction of the total radioactivity present in the filtrate.

Preparation of autolysate. An overnight culture of $B$. cereus was grown to an $A_{540}$ of about $1 \cdot 5$, harvested by centrifuging, chilled to $0{ }^{\circ} \mathrm{C}$, washed twice with phosphate buffer at $2{ }^{\circ} \mathrm{C}$ and then resuspended in phosphate buffer to an $A_{540}$ of 1.5 . After incubation for $7.5 \mathrm{~h}$ at $37^{\circ} \mathrm{C}$, cell debris was removed by centrifugation at $27000 \mathrm{~g}$ for $10 \mathrm{~min}$ and subsequent filtration of the supernatant through a cellulose acetate membrane 
(Millipore, $0.45 \mu \mathrm{m}$ pore size). This filtrate was used in experiments on the release of radioactivity from cells labelled with $\left[{ }^{14} \mathrm{C}\right]$ GlcNAc. When a high autolysin activity was required for demonstrating digestion of isolated walls by decrease of turbidity, cells were washed with sodium barbital buffer, resuspended in the same buffer to an $A_{540}$ of 6.0 and incubated at $37^{\circ} \mathrm{C}$ for $7.5 \mathrm{~h}$.

Preparation of walls. Bacillus cereus was grown in 51 medium to an $A_{540}$ of 1.65. The culture was chilled and the cells were harvested by centrifugation. The pellet was resuspended in $250 \mathrm{ml} 4 \%(\mathrm{w} / \mathrm{v})$ sodium dodecyl sulphate (SDS) and stirred at room temperature for $2 \mathrm{~h}$. Cells were collected by centrifuging and washed five times with $0.85 \mathrm{M}-\mathrm{NaCl}$ to remove the SDS. A cell suspension in water (10 $\left.\mathrm{mg} \mathrm{dry} \mathrm{wt} \mathrm{ml}^{-1}\right)$ was then homogenized in a Braun homogenizer (Braun, Melsungen, Germany) with grade 12 ballotini glass beads. The broken cell suspension was decanted from the glass beads and the beads were washed to recover trapped cell material. Unbroken cells were sedimented by centrifugation at $1000 \mathrm{~g}$ for $5 \mathrm{~min}$ and discarded. Walls were washed and finally collected by centrifugation at $20000 \mathrm{~g}$ for $15 \mathrm{~min}$ and stored as a freeze-dried preparation.

$\mathrm{N}$-Acetylation of walls. Walls were treated with acetic anhydride in $\mathrm{NaHCO}_{3}$ for $2 \mathrm{~h}$ at room temperature according to the method of Heymann et al. (1964).

Turbidity difference measurements. Turbidity difference measurements were used to assess the optical effects of binding of lysozyme to wall suspensions. Two samples $(950 \mu \mathrm{l})$ of a suspension of isolated B. cereus walls $\left(A_{540} 0.55\right)$ in acetate buffer, $\mathrm{pH} \mathrm{6.4}$, of the appropriate molarity were placed in cuvettes in the jacketed carriage of a Unicam SP1800 split-beam spectrophotometer and incubated either at $37^{\circ} \mathrm{C}$ or at 0 to $1{ }^{\circ} \mathrm{C}$. The turbidity difference was monitored continuously on a Unicam AR25 linear recorder. Treatments were made by adding $50 \mu \mathrm{l}$ buffer to the reference wall suspension and $50 \mu \mathrm{l}$ enzyme stock solution $\left(1 \mathrm{mg} \mathrm{ml}^{-1}\right)$ in buffer to the test wall suspension, rapidly followed by mixing of the cuvette contents.

Protein assay. Protein was assayed by the Lowry method with lysozyme as the standard. Samples $(200 \mu 1)$ containing $200 \mathrm{~mm}$-acetate buffer, $\mathrm{pH} 6.4$, were first made alkaline (pH about 9.5 ) by adding $5 \mu 14 \mathrm{M}-\mathrm{NaOH}$. Samples containing $5 \mathrm{M}-\mathrm{LiCl}$ were diluted 25 -fold with water before assay.

Total reducing group assay. The ferricyanide method of Park \& Johnson described by Ashwell (1957) was modified and used for colorimetric assay of total reducing groups. Enzymic activity in samples $(0 \cdot 6 \mathrm{ml})$ was stopped by placing on ice and addition of ice-cold carbonate/cyanide buffer $(0.3 \mathrm{ml})$. After addition of ferricyanide reagent $(0.3 \mathrm{ml})$ and boiling for $15 \mathrm{~min}$, the mixture was cooled and insoluble material was removed by centrifuging for $5 \mathrm{~min}$ in a microcentrifuge (Jobling model 320$)$. To the supernatant $(1 \mathrm{ml})$ was added ferric iron reagent $(1.25 \mathrm{ml})$. After $15 \mathrm{~min}$, when the blue colour had fully developed, the $A_{690}$ was measured and compared with a standard curve prepared using $N$-acetylglucosamine.

\section{RESULTS}

\section{Dechaining of bacteria by lysozyme}

The increase in turbidity of cultures of $B$. cereus was completely unaffected by lysozyme at concentrations from 25 to $200 \mu \mathrm{g} \mathrm{ml}^{-1}$. However, microscopic examination showed that lysozyme rapidly decreased the numbers of individual cells in the chains of bacteria (Fig. 1). Thus, after incubation at $37^{\circ} \mathrm{C}$ for $15 \mathrm{~min}$ with lysozyme $\left(50 \mu \mathrm{g} \mathrm{ml}^{-1}\right)$ about $60 \%$ of the particles were single cells compared with 6 to $12 \%$ before treatment. Even after treatment with lysozyme for $90 \mathrm{~min}$, there was no indication of lysis of cells and their morphology was no different from that in the control culture.

In contrast, when lysozyme was added to bacteria suspended in phosphate buffer at $37^{\circ} \mathrm{C}$, dechaining took place at about the same rate, but it was accompanied by a fall in turbidity that suggested lysis was occurring. Total and viable cell counts were made on samples of both a control and a lysozyme-treated cell suspension in buffer (Table 1). The viable count in the control suspension dropped from $6.2 \times 10^{7}$ to $4.6 \times 10^{6}$ colony-forming units $\mathrm{ml}^{-1}$ during $90 \mathrm{~min}$ incubation at $37{ }^{\circ} \mathrm{C}$ whilst the turbidity dropped to $66 \%$ of its initial value. At the same time, the total number of particles present (including cell ghosts) more than doubled as a result of chain breakage. The addition of lysozyme promoted chain breakage, as indicated by an initial slight increase in viable count, compared with a fall in the control suspension, and by an even larger eventual increase in the total number of bacterial particles (including ghosts). The fact that viable counts never rose to the same extent as total counts presumably indicated that some cells had already undergone lytic damage, during either the primary incubation or the period before growth commenced on the plates. 


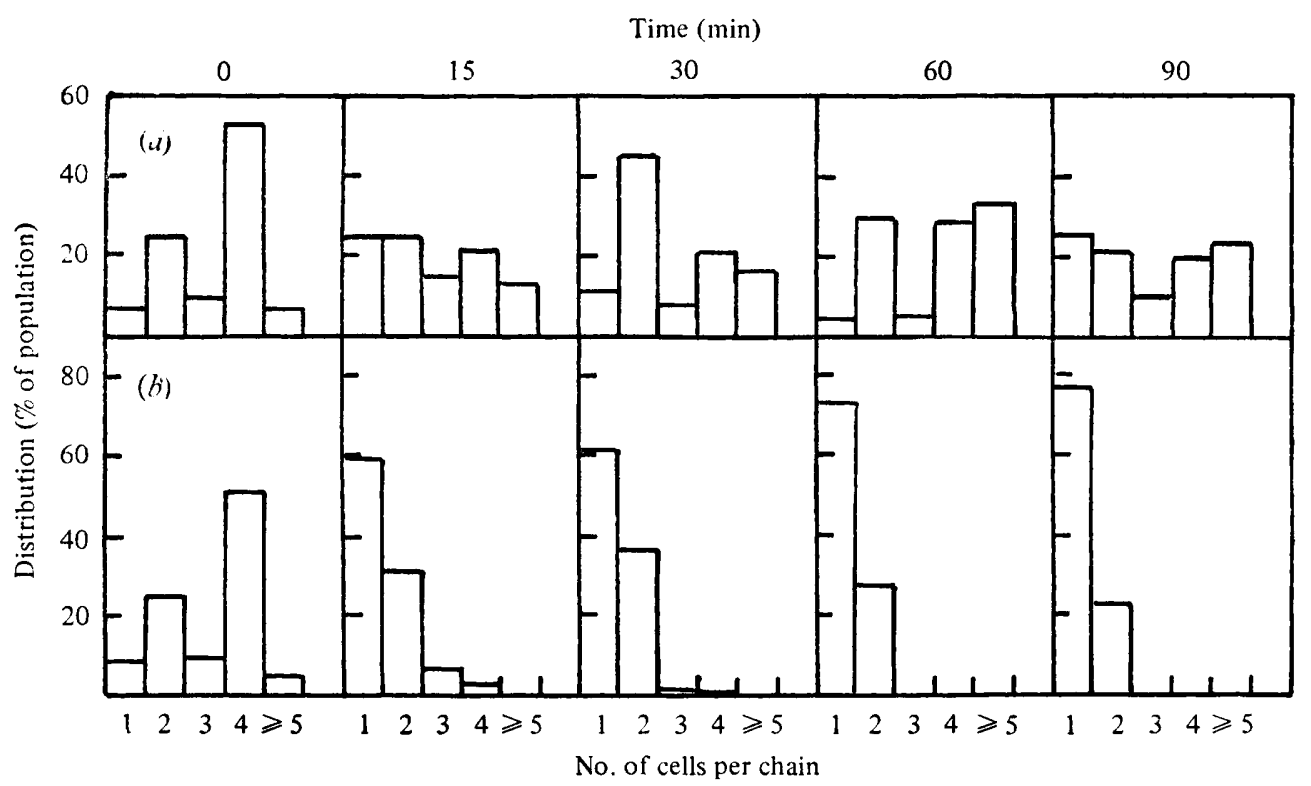

Fig. 1. Distribution of chain lengths in cultures of $B$. cereus: (a) without lysozyme; $(b)$ with lysozyme $\left(50 \mu \mathrm{g} \mathrm{ml}^{-1}\right)$.

Table 1. Effect of lysozyme on viability of $B$. cereus incubated in buffer

Total counts and viable counts were carried out on dilutions of samples from a washed suspension of $B$. cereus incubated in phosphate buffer at $37^{\circ} \mathrm{C}$ with or without lysozyme $\left(50 \mu \mathrm{g} \mathrm{ml}^{-1}\right)$. Weakly stained cell outlines (ghosts) were included in the numbers for the total count. Turbidity $\left(A_{540}\right)$ was also measured and expressed as a percentage of the initial values of 0.82 for the control and 0.84 for the treated suspension.

\begin{tabular}{|c|c|c|c|c|c|c|}
\hline \multirow[b]{2}{*}{$\begin{array}{l}\text { Time } \\
\text { (min) }\end{array}$} & \multicolumn{3}{|c|}{ Untreated (control) } & \multicolumn{3}{|c|}{ Treated with lysozyme } \\
\hline & $\begin{array}{c}\text { Turbidity } \\
\text { (\% of } \\
\text { initial) }\end{array}$ & $\begin{array}{c}10^{-7} \times \text { total } \\
\text { count } \\
\left(\text { cells } \mathrm{ml}^{-1}\right)\end{array}$ & $\begin{array}{c}10^{-7} \times \text { viable } \\
\text { count } \\
\text { (c.f.u. }{ }^{*} \mathrm{ml}^{-1} \text { ) }\end{array}$ & $\begin{array}{c}\text { Turbidity } \\
\text { (\% of } \\
\text { initial) }\end{array}$ & $\begin{array}{c}10^{-7} \times \text { total } \\
\text { count } \\
\left(\text { cells } \mathrm{ml}^{-1}\right)\end{array}$ & $\begin{array}{c}10^{-7} \times \text { viable } \\
\text { count } \\
\text { (c.f.u. }{ }^{*} \mathrm{ml}^{-1} \text { ) }\end{array}$ \\
\hline 0 & 100 & $7 \cdot 2$ & $6 \cdot 2$ & 100 & $7 \cdot 0$ & $7 \cdot 7$ \\
\hline 15 & 100 & $9 \cdot 4$ & $5 \cdot 8$ & 102 & $16 \cdot 2$ & $8 \cdot 4$ \\
\hline 30 & 102 & $10 \cdot 0$ & $5 \cdot 2$ & 102 & $20 \cdot 8$ & $8 \cdot 8$ \\
\hline 60 & 93 & $9 \cdot 2$ & $2 \cdot 6$ & 81 & $24 \cdot 4$ & $0 \cdot 35$ \\
\hline 90 & 66 & $16 \cdot 0$ & $0 \cdot 46$ & 41 & $23 \cdot 0$ & $0 \cdot 02$ \\
\hline
\end{tabular}

\section{Effect of lysozyme on release of wall components}

Preliminary experiments showed that $\left[{ }^{14} \mathrm{C}\right] \mathrm{GlcNAc}$ was incorporated into both accessory polymers and peptidoglycan of $B$. cereus walls (results not shown). When cells labelled with $\left[{ }^{14} \mathrm{C}\right] \mathrm{GlcNAc}$ were resuspended in phosphate buffer and incubated at $37^{\circ} \mathrm{C}$, there was a rapid drop of turbidity to $21 \%$ of the initial value (Fig. $2 a$ ) and a concomitant release of ${ }^{14} \mathrm{C}$ at an approximately constant rate (Fig. $2 b$ ). Solubilization of wall components occurred at nearly twice the rate in the untreated control when lysozyme $\left(50 \mu \mathrm{g} \mathrm{ml}^{-1}\right)$ was added to the cell suspension, with $50 \%$ of the label being released in $2 \cdot 2 \mathrm{~h}$.

When endogenous autolysins were inactivated by heating at $70^{\circ} \mathrm{C}$ for $15 \mathrm{~min}$ and the cells were incubated at $37^{\circ} \mathrm{C}$ in buffer with or without lysozyme, neither a fall in turbidity (Fig. $2 a$ ) nor appreciable release of ${ }^{14} \mathrm{C}$ (Fig. $2 b$ ) was detected. The heat treatment itself accounted for release of $6 \%$ of the incorporated $\left[{ }^{14} \mathrm{C}\right] \mathrm{GlcNAc}$ from these cell suspensions and even when lysozyme-treated, heated cells were incubated for $19.5 \mathrm{~h}$ there was a nett 

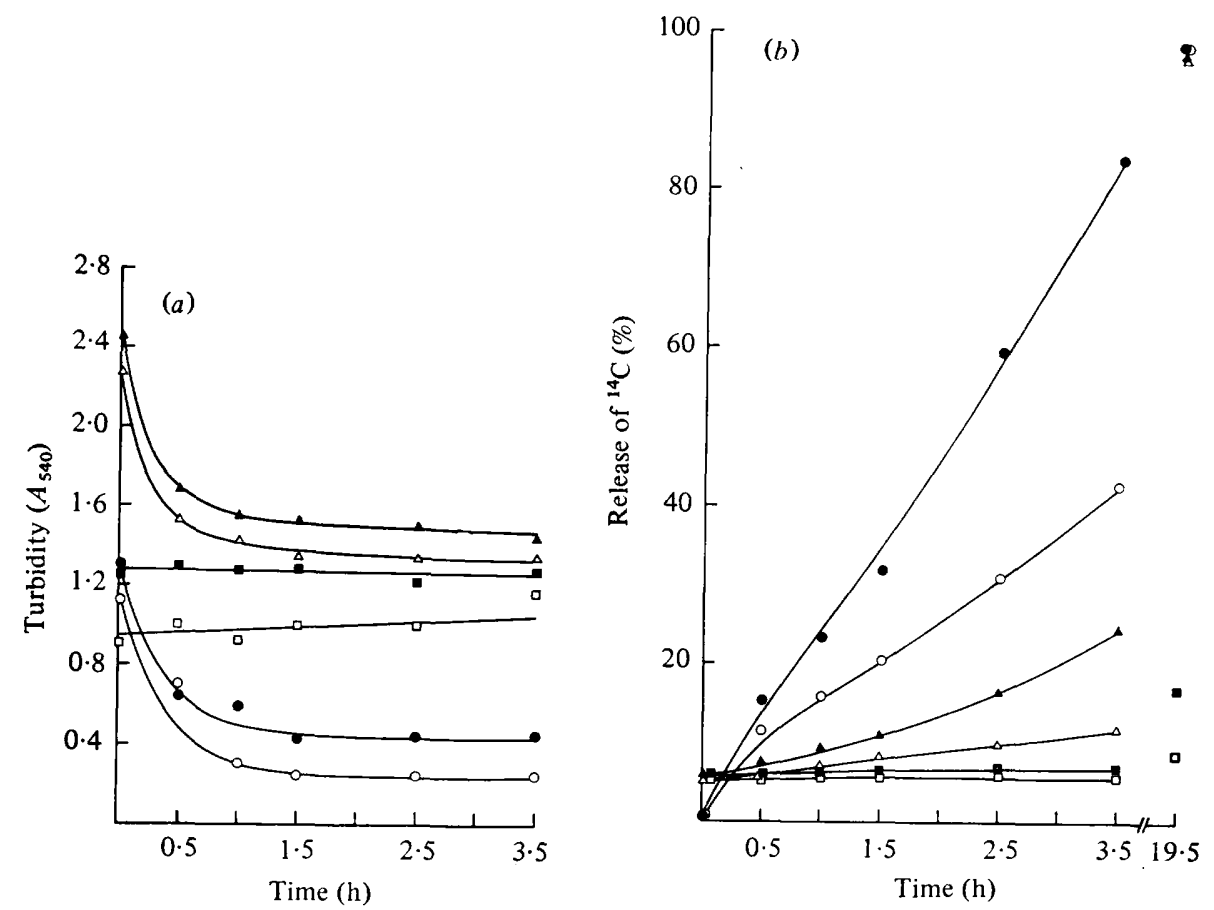

Fig. 2. Effect of lysozyme on lysis of $\left[{ }^{14} \mathrm{C}\right] \mathrm{GlcNAc}$-labelled $B$. cereus as indicated by $(a)$ change of turbidity and $(b)$ release of ${ }^{14} \mathrm{C}$. Reaction mixtures $(10 \mathrm{ml})$ were set up in $100 \mathrm{~mm}$-phosphate buffer, $\mathrm{pH} 6.4$, at $37^{\circ} \mathrm{C}$ containing radioactively labelled cells $\left(1.68 \times 10^{5} \mathrm{~d}\right.$.p.m. ml $\left.{ }^{-1}\right)$ at a final $A_{540}$ of about 1.2 and, where required, lysozyme $\left(50 \mu \mathrm{g} \mathrm{ml}^{-1}\right)$ and additional unheated, unlabelled cells grown in the same way and at the same concentration as those radioactively labelled. Samples $(0.4 \mathrm{ml})$ were removed at intervals, fixed with an equal volume of $10 \%(\mathrm{w} / \mathrm{v})$ aqueous formaldehyde and their turbidity was measured at $540 \mathrm{~nm}$. The turbidity of the reaction mixture was then calculated and plotted against time. Further samples $(1 \mathrm{ml})$ were filtered through cellulose acetate membranes $(0.45 \mu \mathrm{m}$ pore size) and radioactivity in the filtrate was expressed as a percentage of the total activity in the filtrate plus washed filter. $\bigcirc$, Unheated cells; $O$, unheated cells plus lysozyme; $\square$, cells heated at $70^{\circ} \mathrm{C}$ for $15 \mathrm{~min} ; \square$, heated cells plus lysozyme; $\triangle$, heated cells plus unheated, unlabelled cells; $\boldsymbol{\Delta}$, heated cells plus unheated, unlabelled cells plus lysozyme.

release of only $11.4 \%$ of the incorporated ${ }^{14} \mathrm{C}$. It was apparent, therefore, that lysozyme was only able to stimulate autolytic release of wall components and not to lyse the bacilli in the absence of endogenous autolysins.

The radioactive walls of a heated, labelled cell suspension could be effectively solubilized by adding unheated, unlabelled cells to the incubation mixture, this solubilization again being stimulated by the presence of lysozyme (Fig. $2 b$ ). Although the rate of release of ${ }^{14} \mathrm{C}$ was rather slow in these two incubations, the final amount released after $19.5 \mathrm{~h}(96$ to $97 \%$ ) was similar to that released from labelled, unheated cells. The decreases in turbidity observed within $1.5 \mathrm{~h}$ (Fig. $2 a$ ) were assumed to be largely due to the lysis of the unheated, unlabelled cells.

\section{Effect of lysozyme on the lysis of heated, ${ }^{14} \mathrm{C}$-labelled cells by cell-free autolysate}

The enhancement by lysozyme of the release of radioactivity from heated, labelled cells caused by added lysing, unlabelled cells may have been due to an effect of lysozyme on the activity of autolysin released by the unlabelled cells or to a stimulation of autolysin release. Cell-free autolysate was therefore used in an attempt to investigate these possibilities.

Treatment of heat-inactivated, ${ }^{14} \mathrm{C}$-labelled cells with autolysate which was free of lysing cells gave rise to a slight decrease in turbidity and a rapid linear release of ${ }^{14} \mathrm{C}$ during the 


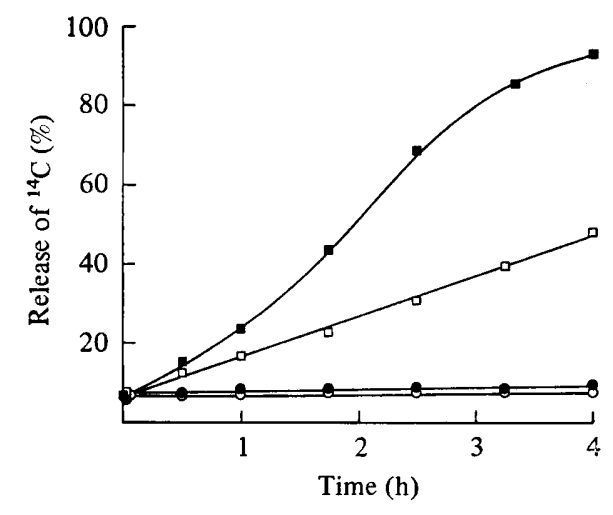

Fig. 3. Effect of lysozyme and cell-free autolysate on lysis of heat-inactivated, $\left[{ }^{14} \mathrm{C}\right] \mathrm{GlcNAc}$-labelled B. cereus as indicated by release of ${ }^{14} \mathrm{C}$. Reaction mixtures $(10 \mathrm{ml})$ were set up in $100 \mathrm{~mm}$-phosphate buffer, $\mathrm{pH} 6 \cdot 4$, at $37^{\circ} \mathrm{C}$ containing heat-inactivated, radioactively labelled cells $\left(1 \cdot 16 \times 10^{5} \mathrm{~d} . \mathrm{p} . \mathrm{m}\right.$. $\left.\mathrm{ml}^{-1}\right)$ and, where required, lysozyme $\left(50 \mu \mathrm{g} \mathrm{ml}^{-1}\right)$ and a twofold dilution of fresh cell-free autolysate prepared as described in Methods. Samples $(1 \mathrm{ml})$ were filtered through cellulose acetate membranes $(0.45 \mu \mathrm{m}$ pore size) and radioactivity in the filtrate was expressed as a percentage of the total activity in the filtrate plus washed filter. $\bigcirc$, Heated cells (initial $A_{540} 0.73$ ); $\bigcirc$, heated cells (initial $A_{540} 0 \cdot 75$ ) plus lysozyme; $\square$, heated cells (initial $A_{540} 0.62$ ) plus autolysate; $\boldsymbol{\omega}$, heated cells (initial $A_{540} 0 \cdot 613$ ) plus autolysate plus lysozyme.

incubation (Fig. 3). Addition of lysozyme again caused a doubling of the rate of release of ${ }^{14} \mathrm{C}$. When the heated cells were incubated without autolysate, there was little change in turbidity and no release of radioactivity even when lysozyme was added. This experiment clearly showed that the stimulatory effect of lysozyme on the lysis of ${ }^{14} \mathrm{C}$-labelled cells by autolysins from actively lysing cells (Fig. $2 b$ ) was not likely to be due to any substantial release of additional autolysins but rather either to an effect on the heated, labelled cells or to a synergistic action with autolysins.

Microscopic examination showed that in the heated, ${ }^{14} \mathrm{C}$-labelled cell suspension $80 \%$ of the particles consisted of pairs. The chains were shorter than those described above, a difference that presumably reflected the variation in the degree of septation of B. cereus at different stages of batch culture. Incubation in buffer for $4 \mathrm{~h}$ with or without lysozyme did not affect the chain length distribution, whereas after addition of autolysate $62 \%$ of the particles in the population were found as single cells within $1 \mathrm{~h}$. Simultaneous addition of autolysate and lysozyme caused even more rapid dechaining, $81 \%$ of the particles being found as single cells within $1 \mathrm{~h}$. Although loss of radioactivity under the latter conditions showed that there was nearly complete solubilization of the walls in $4 \mathrm{~h}$, the whole population remained visible as intact, crystal violet-stained cell shapes.

\section{Sequential treatments of heated, ${ }^{14} \mathrm{C}$-labelled cells with lysozyme and autolysate}

Although the above experiments showed that lysozyme enhanced the rate of lysis caused by exogenous autolysin, this could have been due to lysozyme making walls more sensitive to autolysins, though not digesting them itself, or to intermediates of autolytic digestion being sensitive to lysozyme. After a primary partial treatment of heated, labelled cells with either autolysin or lysozyme, the rates of release of label during a secondary treatment with the other enzyme should indicate the method by which lysozyme enhances autolytic action.

To examine the effect of pre-treatment of cells with autolysin or lysozyme on the rate of release of ${ }^{14} \mathrm{C}$ by lysozyme or autolysin, respectively, a method of inhibiting continued activity of the first treatment was necessary since both autolytic enzymes and lysozyme bind strongly to $B$. cereus walls (unpublished results, and see below). For this purpose, the first treatment was terminated by two washes with $5 \mathrm{M}-\mathrm{LiCl}$ at $0{ }^{\circ} \mathrm{C}$ followed by two buffer washes. Such conditions have been shown to release or inactive autolysins (Fan, 1970 $a$; 


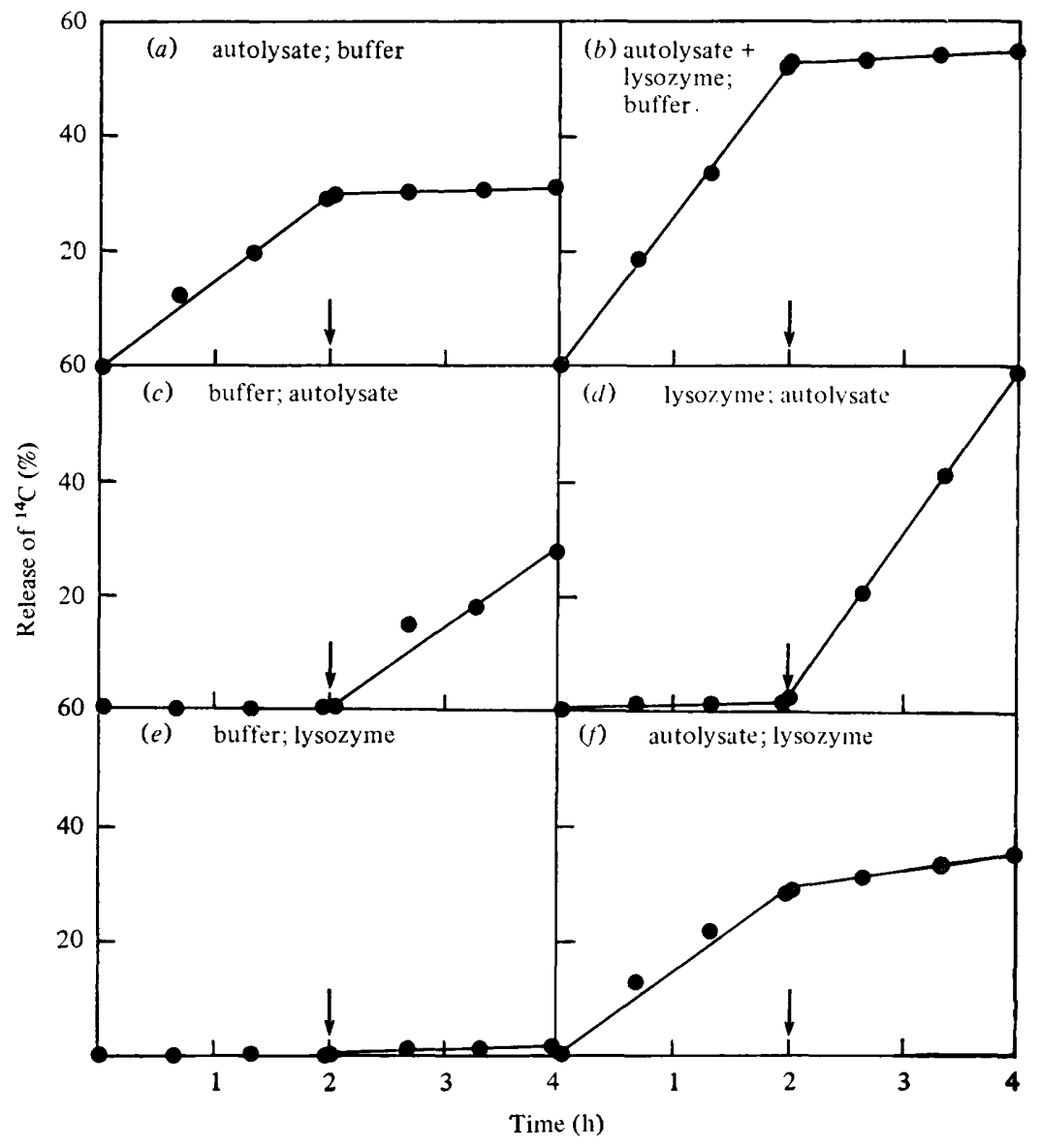

Fig. 4. Release of ${ }^{14} \mathrm{C}$ from heat-inactivated, $\left[{ }^{14} \mathrm{C}\right] \mathrm{GlcNAc}$-labelled $B$. cereus during sequential treatments with lysozyme and autolysate. Six samples (each $8 \mathrm{ml}$ ) from a radioactively labelled, heat-inactivated culture were centrifuged and the cells were resuspended in $9 \mathrm{ml}$ of either phosphate buffer, pH $6.4(c, e)$, autolysate $(a, f)$, lysozyme $\left(50 \mu \mathrm{g} \mathrm{ml}^{-1}\right)$ in phosphate buffer, $\mathrm{pH} 6.4(d)$ or both autolysate and lysozyme $(b)$. During $2 \mathrm{~h}$ incubation at $37^{\circ} \mathrm{C}$, samples $(1 \mathrm{ml})$ were taken and the radioactivity released was measured and expressed as a percentage of the total $\left(4.58 \times 10^{4}\right.$ d.p.m. $\mathrm{ml}^{-1}$ ) present. At $2 \mathrm{~h}$ (arrowed), insoluble material was sedimented by centrifugation at $27000 \mathrm{~g}$ for 5 min at $0{ }^{\circ} \mathrm{C}$, washed twice with $5 \mathrm{M}-\mathrm{LiCl}$ at $0{ }^{\circ} \mathrm{C}$, washed twice with phosphate buffer, pH 6.4 , at $0^{\circ} \mathrm{C}$ and resuspended in $5 \mathrm{ml}$ of either phosphate buffer $(a, b)$, autolysate $(c, d)$ or lysozyme $(e, f)$. During a further $2 \mathrm{~h}$ incubation at $37^{\circ} \mathrm{C}$, samples $(1 \mathrm{ml})$ were taken, the released radioactivity was measured and the results were expressed as the total percentage release of radioactivity by accounting for the removal of soluble radioactivity during the washing procedures.

Brown, 1972; Fan \& Beckman, 1973) and also to release bound lysozyme (see below). Suspensions of heat-inactivated cells, washed to remove radioactivity released during the heating, were used throughout. When lysis of cells with autolysate was stopped by the $\mathrm{LiCl}$ washing procedure, there was no continued solubilization of wall material when the partially digested material was resuspended and incubated in buffer (Fig. $4 a$ ). An enhanced rate of ${ }^{14} \mathrm{C}$-release was observed when both lysozyme and autolysate were used together (Fig. $4 \mathrm{~b}$ ), this solubilization being completely stopped by treatment with $\mathrm{LiCl}$. The rate of ${ }^{14} \mathrm{C}$-release from cells by added autolysate was unaffected by pre-treatment with $\mathrm{LiCl}$ (compare $c$ and $a$, Fig. 4). However, when incubation with lysozyme for $2 \mathrm{~h}$ preceded the $\mathrm{LiCl}$ wash, the subsequent rate of release of radioactivity by autolysate alone was almost doubled and resembled that for treatment with lysozyme and autolysate together (compare $d$ and $b$, Fig. 4). Washing 


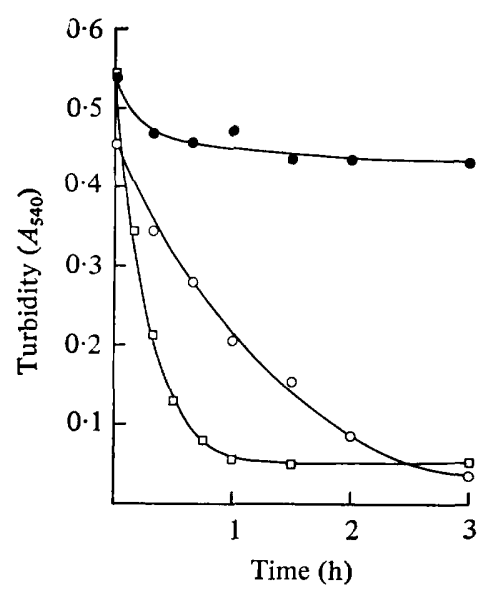

Fig. 5. Effect of lysozyme $\left(50 \mu \mathrm{g} \mathrm{ml}^{-1}\right)$ on digestion of isolated $B$. cereus walls by autolysate. Digestion was followed by measuring the $A_{540}$ of samples from incubations of walls at $37^{\circ} \mathrm{C}$ in $10 \mathrm{~mm}$ barbital buffer, $\mathrm{pH} 8 \cdot 0$. $\bigcirc$, Walls plus autolysate; $O$, walls plus lysozyme; $\square$, walls plus lysozyme plus autolysate.

with $\mathrm{LiCl}$ of cells that had been pre-incubated in buffer did not promote the release of radioactivity when the cells were incubated in lysozyme (compare $d$, left-hand side, and $e$, Fig. 4); however, if cells pre-treated with autolysate and then washed with $\mathrm{LiCl}$ were incubated with lysozyme, a very slight release of ${ }^{14} \mathrm{C}$ was observed in the latter part of the experiment (Fig. $4 f$ ). This may have been due to enhancement of the very low residual activity that survived the $\mathrm{LiCl}$ wash. There was certainly no activity comparable with the stimulated rate observed with lysozyme and autolysate together.

This series of treatments clearly showed that lysozyme made the walls more sensitive to autolytic activity without itself solubilizing them to any extent.

\section{Effect of lysozyme on digestion of isolated walls by autolysate}

In all the above experiments $\left[{ }^{14} \mathrm{C}\right] \mathrm{GlcNAc}$-labelled cells were used, but to characterize chemically the limited action of lysozyme it was necessary to use isolated walls as the enzyme substrate. There was a dramatic stimulation of the rate of decrease of turbidity when walls were treated with autolysate together with lysozyme (Fig. 5). Lysozyme alone had comparatively little effect on the turbidity of the wall suspension after the first $30 \mathrm{~min}$.

Results could not be expressed as a percentage of initial turbidity since it was found that immediately after suspension of walls in lysozyme the turbidity increased by $18 \%$ and then gradually returned to just below the theoretical initial value, within about $30 \mathrm{~min}$. This observation was re-examined by measuring turbidity differences in a split-beam spectrophotometer. Addition of lysozyme (to give $50 \mu \mathrm{g} \mathrm{ml}^{-1}$ ) to the test suspension of walls during incubation in $10 \mathrm{mM}$-acetate buffer, $\mathrm{pH} 6.4$, at $37^{\circ} \mathrm{C}$ caused an immediate $14 \%$ increase in turbidity. The turbidity then gradually decreased over $2 \mathrm{~h}$ to a little below its initial value. Further addition of lysozyme (to give $97.6 \mu \mathrm{g} \mathrm{ml}^{-1}$ ) again immediately increased the turbidity by $18 \%$, but this time further incubation caused only a small decrease. When a similar experiment was carried out at 0 to $1{ }^{\circ} \mathrm{C}$ there was an immediate rise in turbidity but only a slight subsequent decrease. Since an almost identical increase in turbidity occurred when $B$. cereus walls were incubated at $37^{\circ} \mathrm{C}$ with ribonuclease $\mathrm{A}\left(50 \mu \mathrm{g} \mathrm{ml}^{-1}\right.$ ) (also, like lysozyme, a small basic protein), this would suggest that the increase was due to ionic binding of the positively charged protein to wall polymers, whilst the decrease observed during the first incubation at $37^{\circ} \mathrm{C}$ was due to limited biological activity of lysozyme. The increase in turbidity was prevented if the lysozyme and walls were incubated in 200 mM-acetate buffer or in $10 \mathrm{~mm}$-acetate buffer containing $190 \mathrm{mM}-\mathrm{NaCl}$. Assay for free soluble protein during 
treatment of walls with lysozyme indicated that up to $340 \mu \mathrm{g}$ lysozyme can immediately become bound to $1 \mathrm{mg}$ wall in $10 \mathrm{~mm}$-acetate buffer. There was no detectable binding in $200 \mathrm{~mm}$-acetate buffer. When walls loaded with lysozyme [130 $\left.\mu \mathrm{g}(\mathrm{mg} \text { wall })^{-1}\right]$ were washed once with $5 \mathrm{M}-\mathrm{LiCl}$, release of more than $98 \%$ of the enzyme could be detected, thus confirming that the lysozyme was ionically bound.

\section{Assay of free reducing groups in lysozyme-treated isolated walls}

Strains of $B$. cereus differ in the proportion of unacetylated glucosamine residues found in their peptidoglycan and hence in their susceptibility to lysozyme (Araki et al., 1972). To characterize the biochemical basis for the enhancement of autolytic activity in strain 569 brought about by lysozyme, we examined the release of free reducing groups. Walls were suspended in $10 \mathrm{~mm}$-acetate buffer, $\mathrm{pH} 6.4$, and incubated at $37^{\circ} \mathrm{C}$ for $6 \mathrm{~h}$. With no additions, the release of free reducing groups was $5 \mathrm{nmol}(\mathrm{mg} \text { wall })^{-1}$ but with lysozyme $\left(50 \mu \mathrm{g} \mathrm{ml}^{-1}\right)$ it was $53 \mathrm{nmol}(\mathrm{mg} \text { wall })^{-1}$. This release contrasted with a value of $327 \mathrm{nmol}(\mathrm{mg} \text { wall })^{-1}$ for walls which had been fully $\mathrm{N}$-acetylated before incubation. Thus, it appeared that the effects of lysozyme described above were attributable to the hydrolysis of only $15 \%$ of the linkages potentially susceptible to the enzyme in fully acetylated walls.

\section{DISCUSSION}

The observation that cultures of $B$. cereus continued to grow at the same rate as controls when treated with up to $200 \mu \mathrm{g}$ lysozyme $\mathrm{ml}^{-1}$ clearly confirmed the resistance of the strain to lysozyme. However, the occurrence of rapid breakage of chains of cells as a result of the treatment did indicate some effect of lysozyme on the cell walls. The observations suggest that lysozyme might digest a thin layer of wall material which is responsible for maintaining cell-cell contact in chains. The lysozyme-sensitive peptidoglycan, in which a large proportion of the glucosamine residues must be $N$-acetylated (Amano et al., 1977) would have to be of very limited distribution and depth to allow maintenance of viability in the separated cells.

In $B$. subtilis, lysozyme at low concentrations caused similar breakage of filaments but also caused lysis of the cultures (Fan, 1970 b). Breakage of chains of Streptococcus pyogenes, S. faecalis and Clostridium sporogenes by lysozyme was reported by Lominski \& Gray (1961) who suggested that this activity might be due to a bacterial enzyme released from the cells by lysozyme.

The rapid autolysis of washed $B$. cereus, known to be caused by an $N$-acetylmuramoylalanine amidase and an endo- $N$-acetylglucosaminidase, possibly with an accompanying D-alanine carboxypeptidase (Hughes, 1971), was measured by following the decrease in turbidity and the release of $\left[{ }^{14} \mathrm{C}\right]$ glucosamine from previously labelled cells. Autolysis was stimulated by lysozyme and so was the separation of chains of bacteria into single cells. Our experiments showed that in both these phenomena lysozyme potentiated the action of the autolysins, which produced the biological results observed.

All of the $\left[{ }^{14} \mathrm{C}\right]$ glucosamine incorporated into the bacteria could be solubilized by the combined action of lysozyme and endogenous (Fig. 2) or exogenous (Fig. 3) autolysins. Hughes (1971) identified a neutral polysaccharide containing $N$-acetylglucosamine which accounted for $40 \%$ of the wall of B. cereus, similar to that later identified by Mirelman et al. (1973). This accessory polymer must also have been released during the solubilization of walls. Since exactly the same observations of stimulation of autolytic activity by lysozyme have been made using cells labelled with $\left[{ }^{3} \mathrm{H}\right]$ diaminopimelic acid (Westmacott \& Perkins, 1978), it is apparent that the solubilization of walls described here was primarily attributable to digestion of peptidoglycan and the release of accessory polymers was only secondary.

The stimulation of autolytic action by lysozyme could have arisen in a number of ways. However, when the enzymes were added separately, only a pre-treatment with lysozyme followed by autolysins gave stimulated rates of lysis, indicating that lysozyme must act on 
sensitive regions of the wall, thus increasing accessibility or susceptibility to autolysins. Lysozyme caused little decrease in the turbidity of suspensions of walls of $B$. cereus in the studies of Hughes (1971) and Araki et al. (1972) and no release of ${ }^{14} \mathrm{C}$ from $\left[{ }^{14} \mathrm{C}\right] \mathrm{GlcNAc}-$ labelled walls (D. Westmacott, unpublished results). The small but significant decrease in turbidity demonstrated in this paper may have been due to alteration in the compactness of the walls. The limited activity of lysozyme, detected by measuring the release of reducing groups from walls, cleaved only $15 \%$ of the $1,4-\beta$ links susceptible to lysozyme when glucosamine was fully acetylated. This suggests that $15 \%$ of the glucosamine is normally acetylated, since Amano et al. (1977) showed that lysozyme has little or no effect on peptidoglycan oligosaccharides with any unacetylated glucosamine residues. Precisely how this limited breakage of glycan chains increases sensitivity of walls to autolysis is not known. The $\mathrm{N}$ acetylglucosamine deacetylase of $B$. cereus is most active on cross-linked fully polymerized peptidoglycan (Araki et al., 1971) and therefore low molecular weight intermediates of peptidoglycan biosynthesis might be expected to be acetylated and sensitive to lysozyme. The integrity of such material may possibly have an important role in influencing the activity of autolysins on walls. If only newly inserted peptidoglycan is sensitive to lysozyme, this enzyme could possibly be used as a tool to study the progress of expansion and turnover of wall material during the growth of $B$. cereus.

The fact that breakage of chains of cells is stimulated by lysozyme action and that exogenous autolysin(s) also induce dechaining indicates that the bridging material maintaining cell-cell contact is more sensitive than the rest of the wall to the particular autolysin whose activity is stimulated by lysozyme. The only report shedding any light on this conclusion is that of increased sensitivity to autolytic amidase of walls from partial septa over those from end walls in B. subtilis (Fan \& Beckman, 1973). In B. cereus the activity of the autolysin involved in cell separation must normally be such that only limited cell separation occurs. Addition of lysozyme to growing cultures caused complete chain breakage so there must be a fine balance in the control of resistance of the septal wall to autolysis.

Although we have not established whether activity of autolysins on purified peptidoglycan is enhanced by simultaneous treatment with lysozyme, it is unlikely that removal of accessory polymers from walls would alter the response described above. Modulation of autolysin activity in bacilli has been ascribed to lipoteichoic acid (Cleveland et al., 1975), teichuronic acid (Robson \& Baddiley, 1977) and possibly also teichoic acid (Brown et al., 1976). Lipoteichoic acid is unlikely to be present in isolated walls since they were treated with $4 \%$ SDS. Bacillus cereus has also been found normally to lack teichuronic acid (White, 1977). Removal of teichoic acid might cause a decrease in sensitivity to autolysin but any stimulation by lysozyme action would presumably be unaffected.

Hughes (1971) described two major autolytic enzymes in B. cereus and Kawagishi et al. (1979) have recently characterized in strain AHU 1356 an endo-glucosaminidase that attacks peptidoglycan with unacetylated glucosamine residues. An examination of the autolytic activity in the supernatant of lysing cells of strain 569 has shown that both amidase and hexosaminidase activities are present (D. Westmacott, unpublished results). Investigations are being continued to determine which autolysin activity is enhanced by lysozyme action and the exact biochemical nature of the stimulatory action. Such information should suggest which autolysin is involved in cell separation in vivo and possibly why the septum is particularly sensitive to the enzyme.

We thank the Medical Research Council for a Programme Grant. 


\section{REFERENCES}

Amano, K., Hayashi, H., Araki, Y. \& Ito, E. (1977). The action of lysozyme on peptidoglycan with $N$-unsubstituted glucosamine residues. European Journal of Biochemistry 76, 299-307.

Arakı, Y., Fukuoka, S., Oba, S. \& Ito, E. (1971). Enzymatic deacetylation of $N$-acetylglucosamine residues in peptidoglycan from Bacillus cereus cell walls. Biochemical and Biophysical Research Communications 45, 751-758.

Araki, Y., Nakatani, T., Nakayama, K. \& Ito, E. (1972). Occurrence of $N$-nonsubstituted glucosamine residues in peptidoglycan of lysozymeresistant cell walls from Bacillus cereus. Journal of Biological Chemistry 247, 6312-6322.

AsHWEll, G. (1957). Colorimetric analysis of sugars. Methods in Enzymology 3, 73-105.

Brown, W. C. (1972). Binding and release from cell walls: a unique approach to the purification of autolysins. Biochemical and Biophysical Research Communications 47, 993-996.

Brown, W. C., Wilson, C. R., Lukehart, S., Young, F. E. \& Shiflett, M. A. (1976). Analysis of autolysins in temperature-sensitive morphological mutants of Bacillus subtilis. Journal of Bacteriology 125, 166-173.

Buchanan, R. E. \& Gibbons, N. E. (ed.) (1974). Bergey's Manual of Determinative Bacteriology, 8th edn. Baltimore: Williams \& Wilkins.

Cleveland, R. F., HöltJe, J. V., WiCKen, A. J., Tomasz, A., Daneo-Moore, L. \& Shockman, G. D. (1975). Inhibition of bacterial wall lysins by lipoteichoic acids and related compounds. Biochemical and Biophysical Research Communications 67, 1128-1135.

FAN, D. P. (1970a). Cell wall binding properties of the Bacillus subtilis autolysin(s). Journal of Bacteriology 103, 488-493.

FAN, D. P. (1970b). Autolysin(s) of Bacillus subtilis as dechaining enzyme. Journal of Bacteriology 103, 494-499.

Fan, D. P. \& Beckman, B. E. (1973). Structural difference between walls from hemispherical caps and partial septa of Bacillus subtilis. Journal of Bacteriology 114, 790-797.

FeIN, J. E. \& Rogers, H. J. (1976). Autolytic enzyme-deficient mutants of Bacillus subtilis 168. Journal of Bacteriology 127, 1427-1442.

Hayashi, H., Araki, Y. \& Ito, E. (1973). Occurrence of glucosamine residues with free amino groups in cell wall peptidoglycan from bacilli as a factor responsible for resistance to lysozyme. Journal of Bacteriology 113, 592-598.

Heymann, H., Manniello, J. M. \& Barkulis, S. S. (1964). Structure of streptococcal cell walls. III. Characterization of an alanine-containing glucosaminyl-muramic acid derivative liberated by lysozyme from streptococcal glycopeptide. Journal of Biological Chemistry 239, 2981-2985.

Hughes, R. C. (1971). Autolysis of Bacillus cereus cell walls and isolation of structural components. Biochemical Journal 121, 791-802.

KawaGishi, S., Araki, Y. \& Ito, E. (1979). A novel glycosidase, an endo-glucosaminidase active on the cell wall peptidoglycan with $N$-unsubstituted glucosamine residues. FEBS Letters 97, 20-22.

LOMINSKI, I. \& GRAY, S. (1961). Inhibition of lysozyme by 'Suramin'. Nature, London 192, 683.

Mirelman, D., Lotan, R., Bernstein, Y., Flowers, H. M. \& Sharon, N. (1973). Purification and properties of an extracellular polysaccharide containing amino sugars formed by Bacillus cereus. Journal of General Microbiology 77, 5-10.

RoBSON, R. L. \& BADDILEY, J. (1977). Role of teichuronic acid in Bacillus licheniformis: defective autolysis due to deficiency of teichuronic acid in a novobiocin-resistant mutant. Journal of Bacteriology 129, 1051-1058.

SARGENT, M. G. (1975). Control of cell length in Bacillus subtilis. Journal of Bacteriology 123, 7-19.

Westmacott, D. \& Perkins, H. R. (1978). Lysozyme-induced stimulation of Bacillus cereus autolysis. Proceedings of the Society for General Microbiology 5, 52.

White, P. J. (1972). The nutrition of Bacillus megaterium and Bacillus cereus. Journal of General Microbiology 71, 505-514.

WHITE, P. J. (1977). A survey for the presence of teichuronic acid in walls of Bacillus megaterium and Bacillus cereus. Journal of General Microbiology 102, 435-439. 